\title{
UV extreme events in Northeast of Brazil
}

\author{
Eventos extremos de UV no Nordeste do Brasil
}

\author{
Alexandre B. Lopo*1, Maria Helena C. Spyrides ${ }^{1,2}$, Paulo. S. Lucio ${ }^{1,2}$, \\ Sebastião Milton Pinheiro da Silva ${ }^{1,3}$ \\ ${ }^{1}$ Programa de Pós-Graduação em Ciências Climáticas, Universidade Federal do Rio Grande do Norte, Natal, Brasil. \\ ${ }^{2}$ Departamento de Estatística, Universidade Federal do Rio Grande do Norte, Natal, Brasil. \\ ${ }^{3}$ Departamento de Geografia, Universidade Federal do Rio Grande do Norte, Natal, Brasil.
}

\begin{abstract}
The main objective of this paper is to analyze extremes UV episodes in Northeast of Brazil (NEB), generally associated to cloud cover and levels of total ozone column (total ozone). The methodology consisted of the calculation of the 95th percentile to define the extreme value in the seasons of UV in city of Natal-RN (reference city) and analysis of NEB obtained from Ozone Monitoring Instrument (OMI) to UV index, total ozone and cloud cover in dates of extreme events in reference city. The results of UV index for Natal city indicated 14.4 for the extreme event in summer and images selected of OMI showed that extreme event were associated mainly with absence of cloudiness and levels below average annual of total ozone. Analysis of extreme episodes of $U V$ index in NEB indicated that the extreme event occurred in reference city does not happen in the entire region, because of the large spatial variability of cloud cover and total ozone.
\end{abstract}

Palavras-chave: UV Index, ozone total column, cloud cover, Ozone Monitoring Instrument, 95th percentile.

\section{Resumo}

O principal objetivo deste trabalho é analisar episódios extremos de UV na região Nordeste do Brasil (NEB), geralmente relacionados à nebulosidade e aos níveis da coluna total de ozônio (ozônio total). A metodologia consistiu no cálculo do percentil 95 para definir o valor extremo de UV nas estações do ano na cidade de Natal (cidade de referência) e análise de imagens do NEB obtidas do Instrumento de Monitoramento de Ozônio (OMI) do indice de UV, ozônio total e cobertura de nuvens em datas de eventos extremos. Os resultados na cidade de Natal indicaram 14,4 como evento extremo para o índice UV no verão e as imagens selecionadas do OMI mostraram que os episódios diários selecionados foram associados principalmente com ausência de nebulosidade e níveis abaixo da média anual de ozônio. Análise de episódios extremos de índice UV na NEB indicou que o evento extremo ocorrido na cidade de referência não acontece em toda a região, devido à grande variabilidade espacial da cobertura de nuvens e ozônio total.

Keywords: UV index, ozônio total, cobertura de nuvens, instrumento de monitoramento de ozônio, percentil 95.

\footnotetext{
* alexandrelopo@hotmail.com
}

Recebido: 31/01/2014 Revisado: 30/03/2014 Aceito: 14/05/2014 


\section{Introdução}

$\mathrm{T}$ he Ultraviolet Radiation (UV) ranges from 100 $\mathrm{nm}$ and $400 \mathrm{~nm}$ wavelengths $(\lambda)$ and are classified according to the effects on human health and the environment in spectral ranges, as UVA, $315 \mathrm{~nm}$ to 400 $\mathrm{nm}, \mathrm{UVB}$, at $280 \mathrm{~nm}$ to $315 \mathrm{~nm}$ and UVC, 100 to 280 $\mathrm{nm}$ [1]. The radiation in the UVC range corresponds to approximately $1 \%$ of solar emissions and does not reach the earth's surface due to the strong absorption in the atmosphere by ozone and molecular oxygen $[2,3]$..

The amount of solar UV radiation $(280-400 \mathrm{~nm})$, that reaches the Earth's surface, is affected mainly by the atmosphere (absorption of ozone, cloudiness, aerosols and pollutants in the troposphere) and the reflectivity of the ground, which is composed in large part for UVA $(90 \%)$ and to a lesser degree of UVB $(10 \%)[4,5]$.

The UV causes various effects on terrestrial and aquatic ecosystems and inorganic materials $[1,6]$. Despite some beneficial effects [7], an inadequate and prolonged human exposure to UV can result in adverse effects, which may be both acute and chronic [6]. The negative effects are manifested predominantly on the skin by means of cancer, burns and erythema [8] and premature aging, as well as they may affect the eyes [9] and immune system [10].

Different aspects of exposure characterize skin cancer: non-melanoma skin cancer or not malignant (NMSC) and melanoma skin cancer or malignant (MSC). There are estimates that NMSC (134.000 new cases) is the most frequent in the Brazilian population and corresponds to $25 \%$ of all tumors [11]. In comparison, MSC causes a high fatality rate but occurs less frequently. In the capitals of the Northeastern Region of Brazil (NEB), NMSC is the second most frequent type of cancer (34.69/100 thousand) for men and the most frequent for women (31.17/100 thousand) [11].

The Ultraviolet Radiation index (UV index) is an important resource that increases public awareness to the risks of overexposure to the sun. Its function is to describe the level or intensity of UV on the surface of the planet and it is used as a warning to people to protect themselves from UV. This index is independent of genotypic factors, thus it is universally applicable to any individual of the population, without regard to their skin color [1]

$\mathrm{UV}$ in the atmosphere is attenuated by processes such as absorption or scattering by ozone total column (total ozone), aerosol particles and cloud cover $[1,5]$. The amount of ozone in the atmosphere is recovering as a result of the Montreal Protocol [3]. Despite the recovery of the total ozone in high latitudes, there was an increase in the surface UV [12 -14]. In the more populated regions, the highest increase of UV has been found in the Southern Hemisphere, including the NEB, in latitudes from -20 to 0 [14].

The presence of aerosols in the atmosphere can be observed through a parameter called Aerosol Optical Depth (AOD). This variable is an extinction measurement (no dimension) of radiation and its interaction with aerosol particles in the atmosphere, mainly due to the processes of spreading and absorption [15-17].

An analysis of such defined extreme events reveals a significant decline in the number of low events, whereas the high events increased by about the same amount. However no significant trend is observed in the magnitude of extreme events. These measurements were used to investigate vertically trends in total ozone in the period 1994-2011 and for establishing an climatology [18].

Research on extreme events of UV index in Spain indicated that cloud cover usually attenuates the ultraviolet (UV) solar radiation but, under certain sky conditions, the clouds may produce an enhancement effect increasing the UV levels at surface. This phenomenon was characterized by a quick and intense increase of UV radiation in surface under broken cloud fields (5-7 oktas) in which the Sun was surrounded by cumulus clouds [19].

The main objective of this paper is to analyze extremes events UV episodes in Northeastern Brazil, generally associated with levels of total ozone and cloud cover.

\section{Materials and methods}

\subsection{Study area}

The study area covers the region of Northeastern Brazil (NEB).

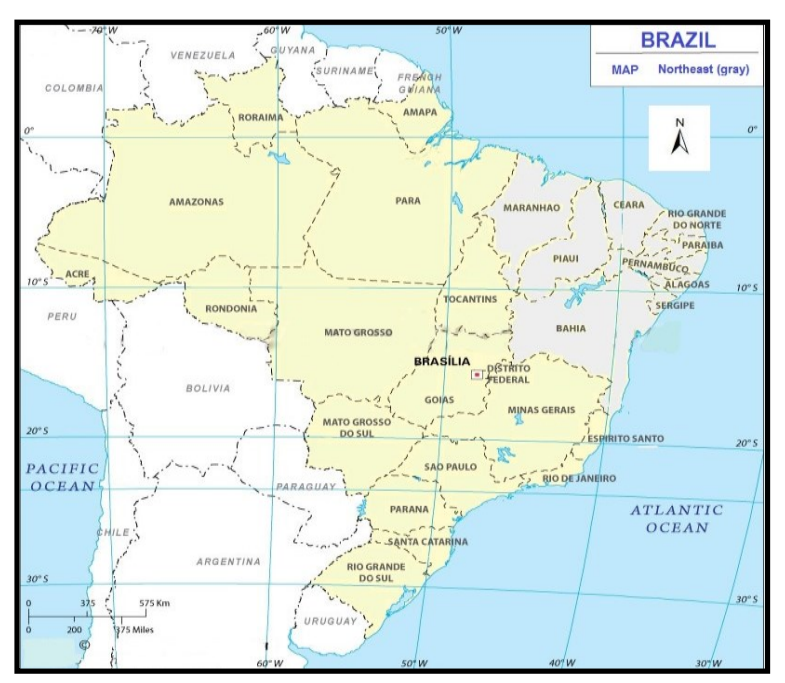

Figure 1- Location of Brazil (colorful) in South America. Northeastern states are indicated in gray.

The measurement of UV in ground was based on radiometers located in capital do Rio Grande do Norte (Natal, latitude $5^{\circ} 48^{\prime} \mathrm{S}$ and longitude $35^{\circ} 12^{\prime} \mathrm{W}$ ), is thus regarded as the city of reference for this study from UV. 


\subsection{Selection of days with extreme events and data}

The selection of days with extreme events was based on measurement in soil and in defining the 95th percentile [20].

The daily data (2001-2012) of UV Index were measured in the surface by: (a) Radiometer GUV (Ground-based Ultraviolet Radiometer) installed in Laboratory of Tropical Environmental Variables of National Institute for Space Research/Center Regional of Northeast (INPE/ CRN/LAVAT) and (b) Sensor Model UV-6490 of Meteorological Station Davis installed at the Laboratory of Hydraulic Machines and Solar Energy in Technology Center of Federal University of Rio Grande of Norte (UFRN/LMHES). The daily maximum of UV index was collected on interval of $11 \mathrm{~h}-13 \mathrm{~h}$, independent of sky conditions. The data have missing values due to lack of operation of the measuring instruments.

The data of Cloudiness (range 0-10), were obtained from the database of meteorological data for Teaching and Research (BDMEP) of the National Institute of Meteorology of Brazil [21].

A set of daily data (2001-2012) of ozone total column (DU units) was collected at TOMS (Total ozone Mapping Spectrometer) e OMI (Ozone Monitoring Instrument) [22].

The pictures or images of UV index, total ozone and cloud cover measurement were made in the NEB by instruments TOMS and OMI $[22,23]$.

\subsection{TOMS and Satellite data-AURA/OMI}

The Total ozone Mapping Spectrometer - TOMS is an atmospheric sensor that has been flying on different missions within NASA's Earth Probes Program. The objective of the mission is to extend the global ozone data set that began in 1978, with the flight of TOMS on NIMBUS-7. The end of the operation occurred in 2005, when it was on board of the Terra Probe platform [24]. The Ozone Monitoring Instrument-OMI is an instrument launched in July 2004 on board of EOS-Aura platform.

Aura is the atmospheric chemistry mission of NASA's platform Earth Observing System (EOS) launched on 15 July 2004. Ozone Monitoring Instrument (OMI) is a nadir viewing spectrometer designed to monitor ozone and other atmospheric species. OMI covers the wavelength range from 264 to $504 \mathrm{~nm}$ [25]. The OMI surface UV algorithm first estimates the clear-sky surface irradiance using the total column ozone measured by OMI, climatological surface albedo, altitude, solar zenith angle, and latitude-dependent climatological ozone and temperature profiles [26, 27]. Next, the clear-sky irradiance is multiplied by a factor that accounts for the attenuation of UV radiation by clouds and no absorbing aerosols. The current algorithm [29] does not account for absorbing aerosols or organic carbon, smoke, and dust and trace gases (NO2, SO2), which are known to lead to systematic overestimation of the surface UV irradiance and neglects the cirrus effect on UV radiation [28]. The OMI derived surface UV irradiances are expected to show overestimation for regions that are affected by absorbing aerosols $[27,28]$.

Greatest overestimations are anticipated for regions affected by urban pollution and for major natural aerosol episodes. The UV irradiances are calculated once a day for local solar noon. Corrections are not made for possible changes in cloudiness or total column ozone between the local noon and satellite overpass time. The OMUVBd (version 3) data product selected are TOMS -like daily L3 gridded (lat-lon $1^{\circ} \times 1^{\circ}$ ) data product [28]. The UVI are provided at the time of overpass and at solar noon for overpass conditions (labelled OMI) and for clear sky conditions (OMI-CS) [27, 28].

To validate the OMI data, comparisons were done with the UV radiation measured in 18 ground-based stations [29]. For flat, snow-free regions with modest loadings of absorbing aerosols or trace gases, the OMI derived daily erythemal doses have a median overestimation of 0 to $10 \%$, and some 60 to $80 \%$ of the doses are within $\pm 20 \%$ from the ground reference. For sites significantly affected by absorbing aerosols or trace gases one expects, and observes, bigger positive bias up to $50 \%$ is observed. For high-latitude sites the satellitederived doses are occasionally underestimated by up to $50 \%$ because of unrealistically small climatological surface albedo $[27,28,30]$.

OMI monitors the recovery of the ozone layer in response to the phase out of chemicals, such as chlorofluorocarbon (CFCs). Together with its companion instruments Microwave Limb Sounder (MLS) and High Resolution Dynamics Limb Sounder (HIRDLS) it will measure criteria pollutants such as $\mathrm{O}_{3}, \mathrm{NO}_{2}, \mathrm{SO}_{2}$ and aerosols $[28,30]$.

\subsection{UV Index-Formulation}

The UV index was formulated by the International Commission on Illumination (CIE) based on the reference spectrum of action erythema and describes the intensity of UV in relation to its photo biological effect [31]. The UV index is defined by Equation 1.0:

$$
\mathrm{IUV}=\mathrm{K}_{e r} \int_{250 \mathrm{~nm}}^{400 \mathrm{~nm}} \mathrm{E}_{\lambda} \mathrm{S}_{\mathrm{er}}(\lambda) \mathrm{d} \lambda,(1.0)
$$

in which $E_{\lambda}$ is the spectral irradiance expressed in W.m-2nm- 1 to the wavelength $\lambda$ and $\mathrm{d} \lambda$ is the wavelength range used in the integral calculus. $S_{\text {er }}(\lambda)$ is the reference action spectrum erythema and $\mathrm{K}_{\mathrm{er}}$ is a constant equal to $40 \mathrm{~m}^{2} / \mathrm{W}$.

The UV index is the standardization of erythema irradiance $\left(\mathrm{S}_{\mathrm{er}}\right)$ by means of a numerical scale, such that 
$1 \mathrm{UV}$ index $=2.5 \mathrm{~mW} / \mathrm{m}^{2}[1]$. The index is an integer and dimensionless that representing the maximum daily value in a horizontal surface. The UV index is divided into categories associated with the colors (Table 1).

Table 1. Relationship between UV index and category of risk to humans. Source: [1]

\begin{tabular}{ccc}
\hline Category of Risk & Range of UV Index & Color \\
\hline Low & 0 to 2 & Green \\
Moderate & 3 to 5 & Yellow \\
High & 6 to 7 & Orange \\
Very High & 8 to 10 & Red \\
Extreme & $>11$ & Violet \\
\hline
\end{tabular}

The UV index was proposed by the World Health Organization (WHO) and World Meteorological Organization (WMO) to facilitate the understanding of the population about the effects of UV on human beings. The precautions to be taken by the individual, in accordance with the Table 1, refer to the use of hats, clothes, sunglasses, sunscreen, and umbrellas or even to stay inside the house [1].

\section{Results}

\subsection{Descriptive study}

The averages in study period (2001-2012) to UV index and total ozone were respectively $11 \pm 0.2$ and $264.8 \pm 1.8$ DU.

The variability and monthly and annual average of UV index, total ozone and cloud cover are presented in Table 2, Table 3 in Figure 2. The colors in the graph of UV Index are associated with the categorization of risk of the WHO. The UV index reaches the value classified as 'extreme' (color violet) in seven months of the year, between spring and summer.

The annual variability of UV Index in city of Natal has a stabilization/reduction in September and October associated with a higher ozone concentration. The cloud cover does not change during these months [31, 32]. This feature was observed in this data series, as shown in Figure 2.
Table 2. Monthly average of UV index, total ozone and cloud cover (Natal-RN, 2001-12).

\begin{tabular}{rrrr}
\hline Month UV index & Total ozone & $\begin{array}{r}\text { Cloud } \\
\text { cover }\end{array}$ \\
\hline Jan & 11.8 & 259.9 & 7.3 \\
Feb & 12.7 & 259.3 & 7.2 \\
Mar & 12.6 & 262.5 & 7.1 \\
Apr & 11.5 & 259.0 & 7.3 \\
May & 10.2 & 256.1 & 7.0 \\
Jun & 8.8 & 257.7 & 7.3 \\
Jul & 8.8 & 264.3 & 6.8 \\
Aug & 10.3 & 270.7 & 6.6 \\
Sep & 10.6 & 278.6 & 6.6 \\
Oct & 11.6 & 275.9 & 6.6 \\
Nov & 11.8 & 269.7 & 6.6 \\
Dec & 11.1 & 263.6 & 7.0 \\
\hline
\end{tabular}

Source: INPE/CRN-LMHES/UFRN, TOMS-OMI/AURA and INMET.

Table 3. Annual average of UV index, total ozone and cloud cover (Natal-RN, 2001-12).

\begin{tabular}{rrrr}
\hline Year & UV index & Total ozone & $\begin{array}{r}\text { Cloud } \\
\text { Cover }\end{array}$ \\
\hline 2001 & 10.9 & 268.1 & 7.0 \\
2002 & 10.9 & 275.2 & 7.0 \\
2003 & 11.1 & 269.1 & 6.9 \\
2004 & 10.7 & 274.2 & 7.1 \\
2005 & 11.0 & 257.0 & 6.8 \\
2006 & 10.9 & 264.4 & 6.8 \\
2007 & 11.4 & 257.9 & 7.0 \\
2008 & 10.6 & 266.9 & 7.1 \\
2009 & 10.2 & 257.8 & 6.9 \\
2010 & 11.3 & 263.4 & 6.7 \\
2011 & 11.0 & 262.9 & 7.3 \\
2012 & 10.9 & 260.5 & 6.9 \\
$2001-12$ & 11.1 & 264,5 & 7.0 \\
\hline
\end{tabular}

Source: INPE/CRN-LMHES/UFRN, TOMS-OMI/AURA and INMET. 

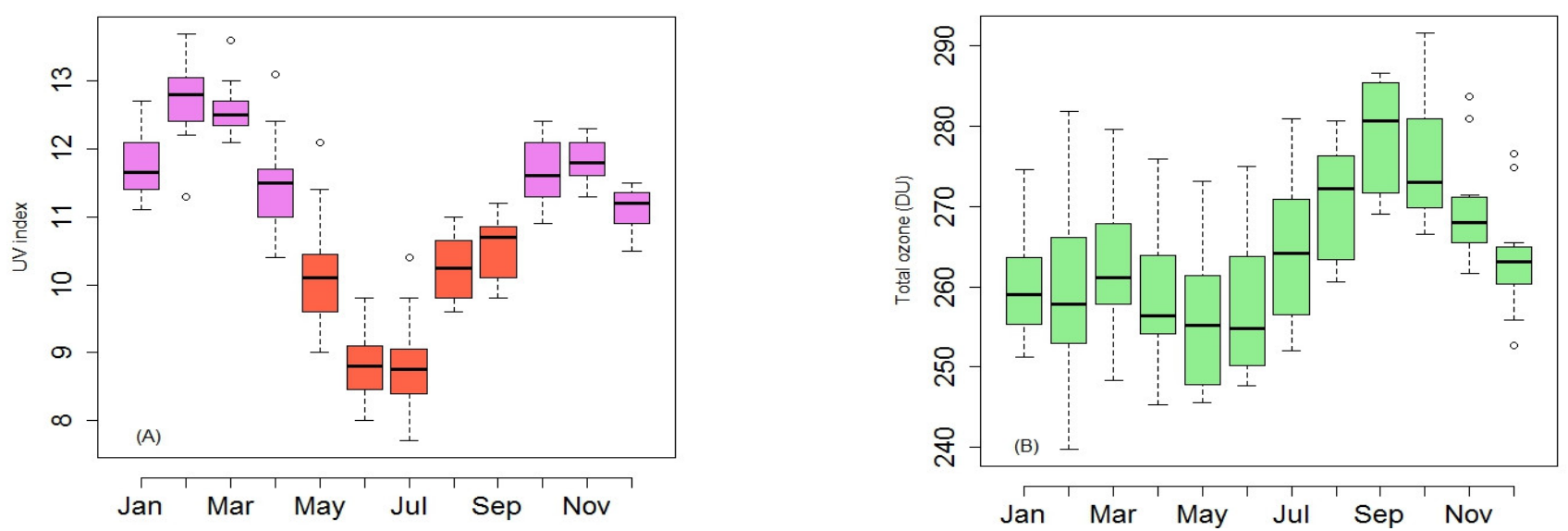

Figure 2- Boxplot of monthly variability to UV Index (A), total ozone (B) and cloud cover (C) to Natal-RN for period 2001-2012.

Source: INPE/CRN-LMHES/UFRN, TOMS-OMI/AURA and INMET.

\subsection{Extreme events of UV index in Natal city and Northeast of Brazil}

The extreme values to the UV index were calculated using the 95th percentile, encountering for each season values: summer, 14.4 , autumn, 13.8 , winter, 11.7 , spring, 13.1

The extreme episodes of UV index were selected of summer in the data series using analysis of Figure 3 and 95th percentile. The reason for the choice of episodes in summer was due the higher extreme values of series occurred during this period of year. The Table 4 presented the extreme values found considering the criteria cited.

The extreme episodes for UV index are completely linked to values below or near the annual average of total ozone $(\approx 265 \mathrm{DU})$ and partially associated with the extreme values of total ozone as the 5th percentile (245.6 DU) and 10th percentile (249.6 DU) or 20th percentile (252.9 DU).

The following Figures (4-7) obtained at OMI show four of events of Table 4 randomly selected. The images show the variables UV index, total ozone and cloud cover about the Northeast of Brazil.
Table 4- Extreme events of UV index and total ozone in Natal-RN (2001-2012).

\begin{tabular}{rrrrrr}
\hline Year & Month & Day & UV Index & Ozone & The \\
\hline 2005 & 2 & 16 & 15.2 & 251.0 & F i - \\
2006 & 2 & 25 & 15.1 & 262.3 & re 4 \\
2007 & 2 & 10 & 15.4 & 246.4 & \\
2008 & 1 & 16 & 14.9 & 258.8 & \\
2009 & 1 & 30 & 14.4 & 248.3 & \\
2010 & 3 & 28 & 15.3 & 245.8 & \\
2011 & 2 & 21 & 14.4 & 267.3 & \\
2012 & 2 & 17 & 14.7 & 248.9 &
\end{tabular}

Source: INPE/CRN-LMHES/UFRN and TOMS-OMI/AURA

shows that the extreme value of the UV index (13-14) in Natal (cityreference) is associated with low levels (10th percentile) of total ozone (248-250 DU) that occurring

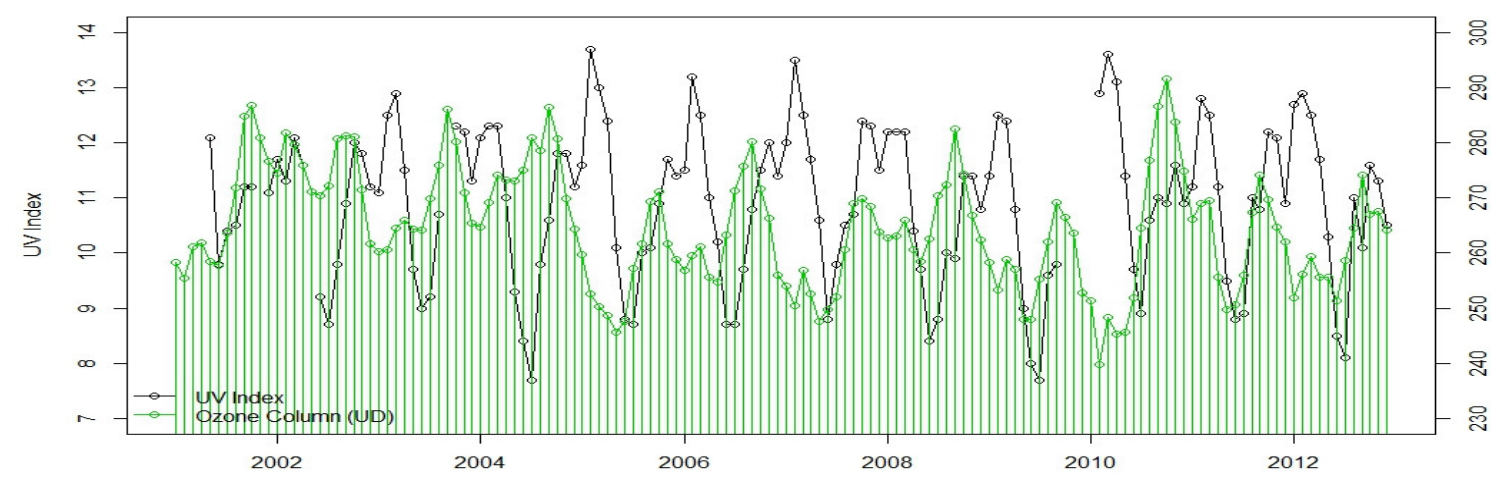

Figure 3 - Time series of UV Index X Ozone total (scale on the right side) for period 2001-2012 in Natal-RN. Source: INPE/CRN-LMHES/UFRN and TOMS-OMI/AURA 


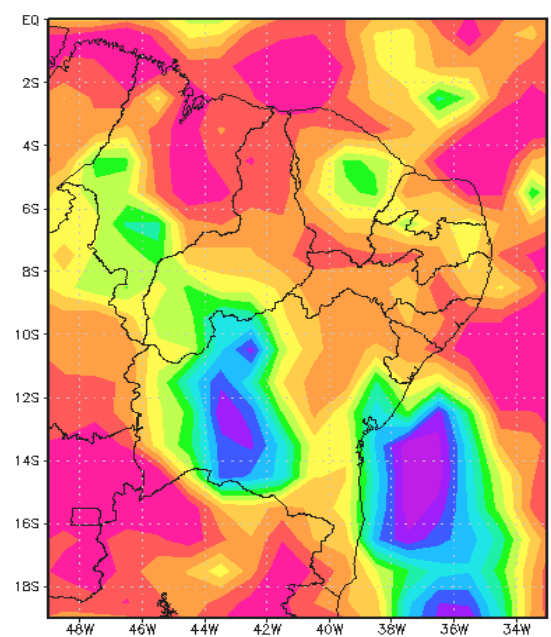

(a) UV index

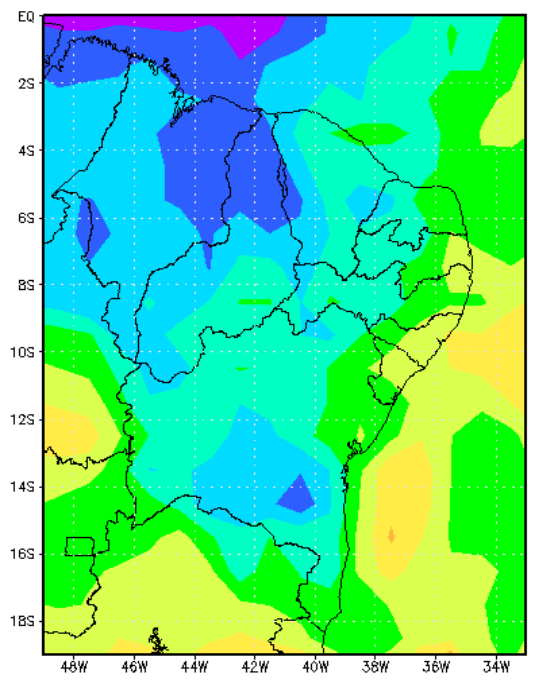

(b) Total Ozone

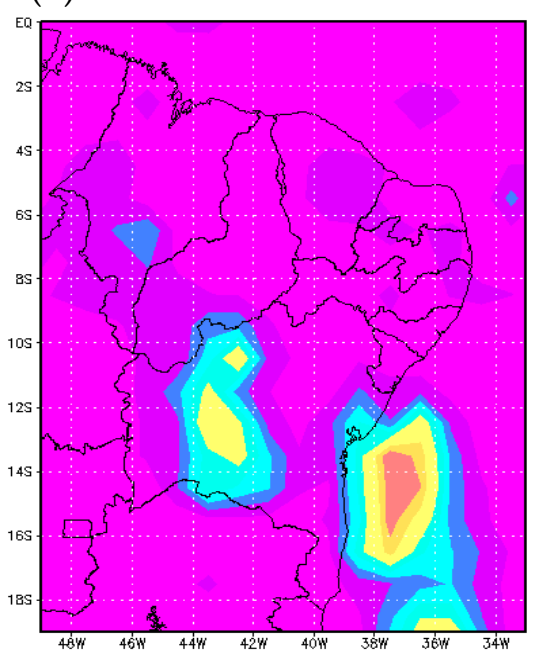

(c) Cloud Cover
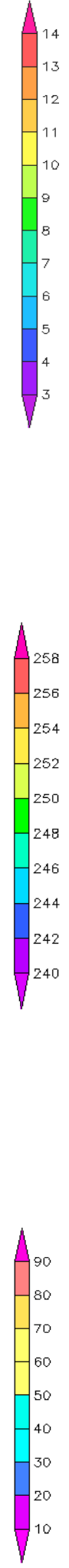

Figure 4- Images the UV index, total ozone and cloud cover for February 16, 2005.

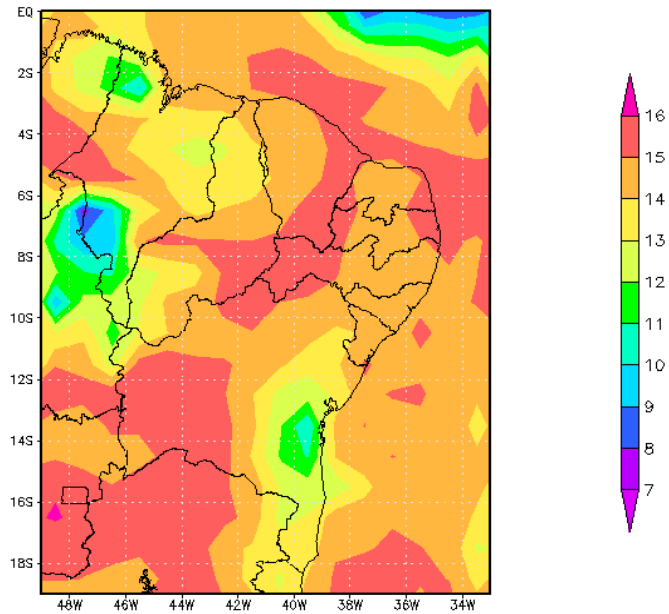

(a) UV index

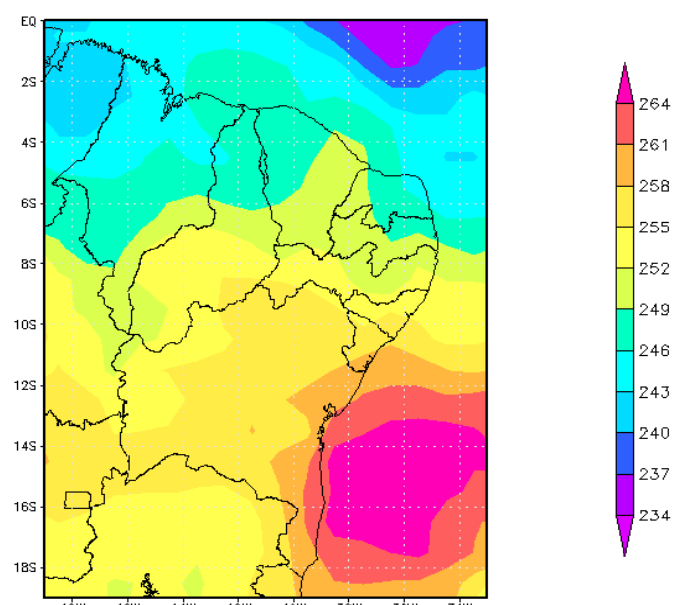

(b) Total Ozone

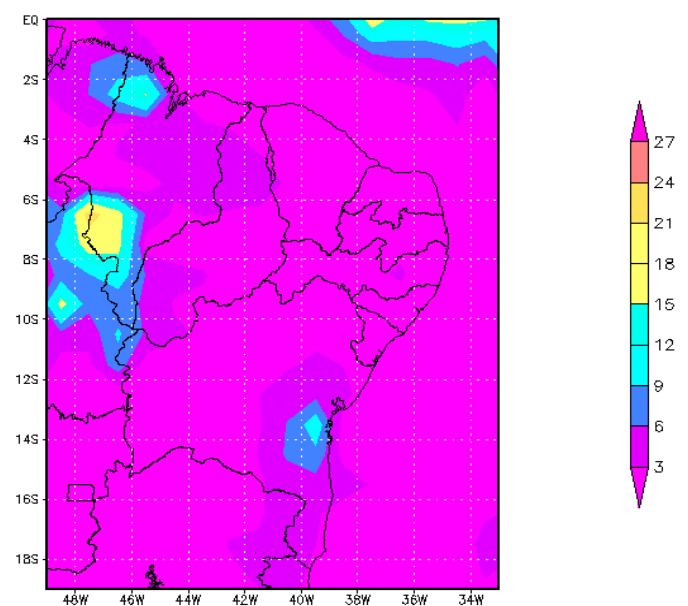

\section{(c) Cloud Cover}

Figure 5- Images the UV index, total ozone and cloud cover for February 10, 2007. 


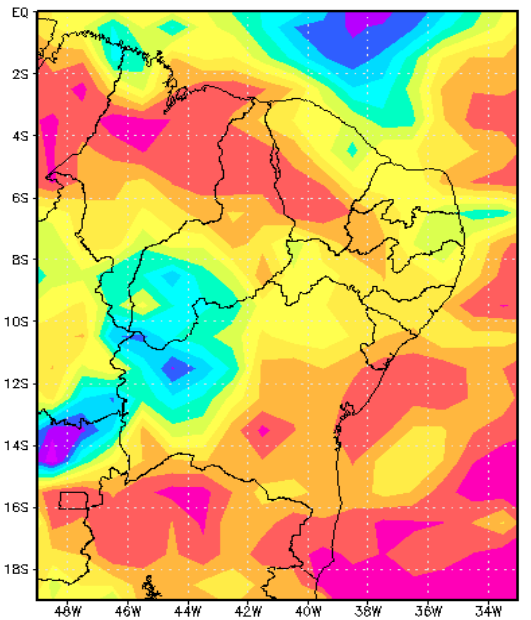

(a) UV index
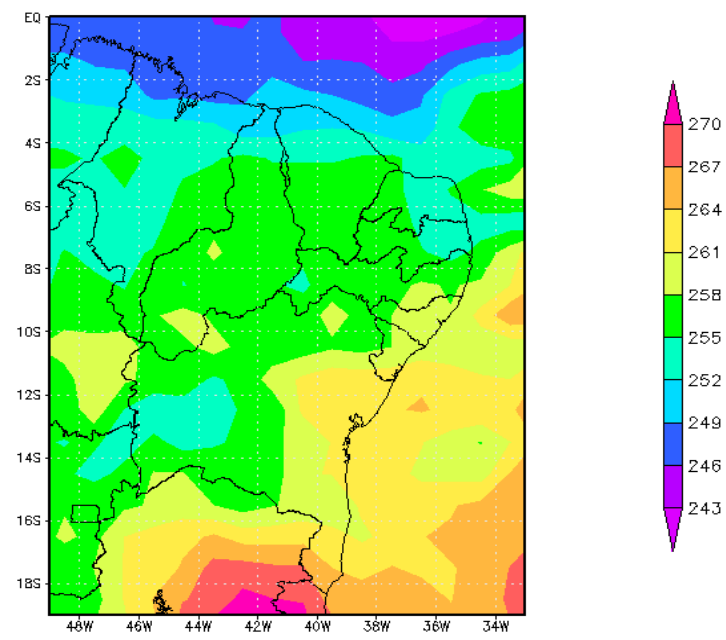

(b) Total Ozone

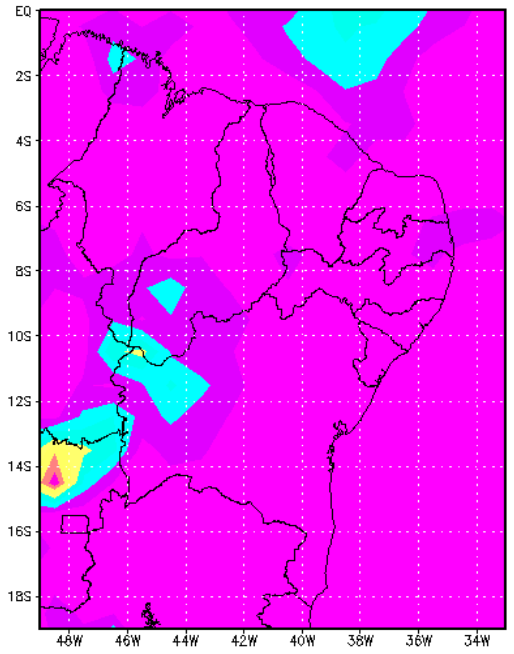

(c) Cloud Cover

Figure 6- Images the UV index, total ozone and cloud cover for January 16, 2008.

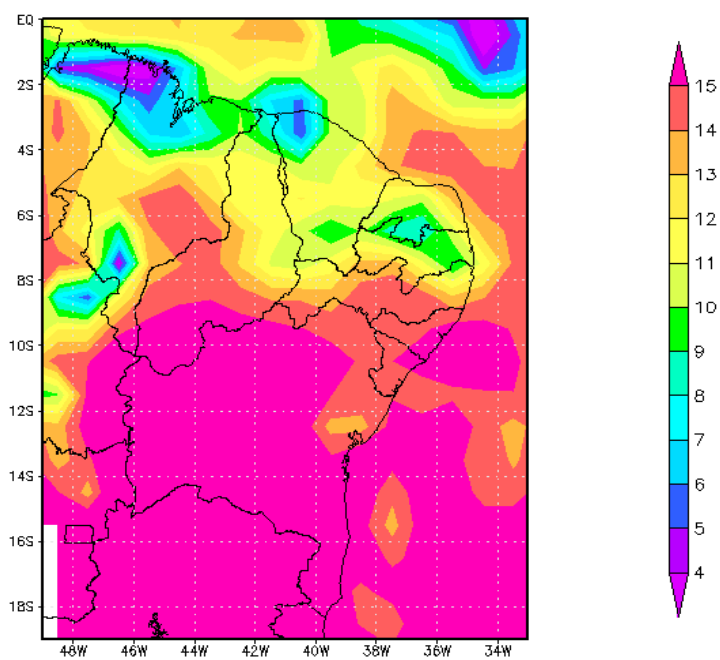

(a) UV index

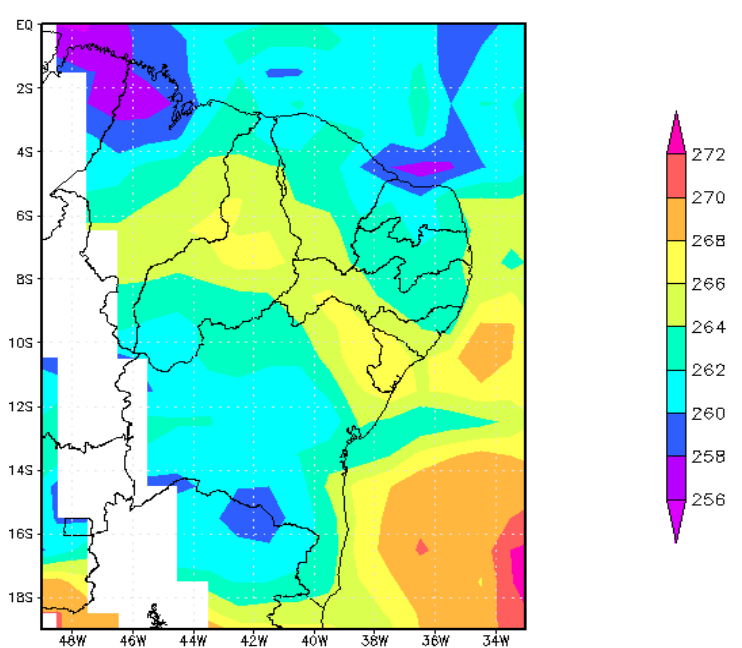

(b) Total Ozone

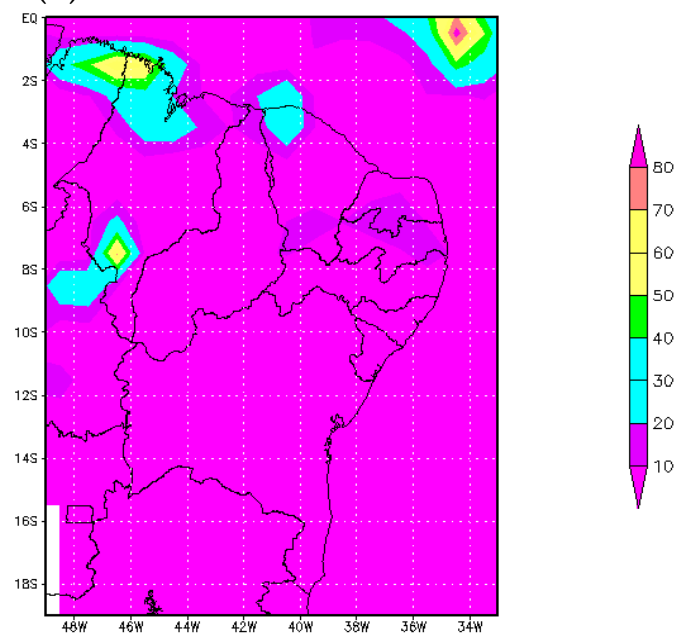

(c) Cloud Cover

Figure 7- Images the UV index, total ozone and cloud cover for February 21, 2011 
during the summer and absence of clouds. The presence of clouds on the coast and interior in state of Bahia (BA) greatly reduce the UV index.

The Figure 5 show that the extreme value of the UV index (15-16) in reference city is associated with low levels (5th percentile) of total ozone (243-246 DU) and lack of clouds. The extreme event of UV index also occurs in western of states of Rio Grande do Norte (RN), Paraiba (PB), Pernambuco (PE), inner of BA and coast of Ceará (CE) associated with low levels (20th percentile) of total ozone (249-252) DU.

In Figure 6 is not confirming an extreme value of the UV index (11-12) in the city of reference. The total ozone (255-258 DU) is in the 25th percentile (255 DU) and there is a slight cloudiness. There are episodes of extreme UV index in coast of BA, center of CE and in northern of states of Piauí (PI) and Maranhão (MA) due to lower levels of total ozone (252-255 DU).

The Figure 7 shows high values for UV index (1314) very near the extreme value (14.4) for the city of reference. The total ozone (262-264 DU) presents below and close to the annual average. There is not cloudy in Natal-RN. Extreme values of UV were confirmands in coast and inner of BA and in coast to states of Sergipe (SE) and Alagoas (AL). At the center of PI, northeast of BA and west PE the UV index is attenuated by the increase of total ozone.

Generally, the images show that the extreme values of the UV index are associated with absence of clouds and levels below the annual average of total ozone.

The extreme event in the reference city did not happen in the whole region of the study, in function of the spatial variability of total ozone and cloud cover in the region.

\section{Final considerations}

In the summer happens the greatest extremes of annual series, so the extreme episodes of UV index in Natal-RN (reference city) were analyzed considering the by 95th percentile (14.4).

The analysis of images of the OMI indicated that the extreme events selected of measurements made at the surface by radiometer GUV were associated mainly with absence of cloudiness and levels below average annual of total ozone. The analysis indicated that the extreme event occurred in reference city does not happen in the entire region of study, because of the large spatial variability of cloud cover and total ozone.

\section{Acknowledgements}

This work was supported by the CNPq, National Council for Scientific and Technological Development, Brazil: Doctor Sandwich - SWE/CsF (246611/2012-0).

The author thanks the Universidade Estadual da
Bahia by financial support during the PhD of PPGCC/ UFRN and to Instituto Federal de Educação, Ciência e Tecnologia da Bahia by study leave.

\section{References}

[1] WORLD HEALTH ORGANIZATION et al. Global solar UV index: A practical guide. 2002.

[2] MADRONICH, Sasha.UV radiation in the natural and perturbed atmosphere. Lewis Publisher, Boca Raton, 1993.

[3] Scientific assessment of ozone depletion: 2010. WMO, 2011.

[4] LIOU, Kuo-Nan. An introduction to atmospheric radiation. Academic press, 2002.

[5] SABBURG, J.; WONG, J. The effect of clouds on enhancing UVB irradiance at the earth's surface: a one year study. Geophysical Research Letters, v. 27, n. 20, p. 3337-3340, 2000.

[6] MADRONICH, Sasha; DE GRUIJL, Frank R. Skin cancer and UV radiation. 1993.

[7] WEBB, Ann R.; HOLICK, Michael F. The role of sunlight in the cutaneous production of vitamin D3. Annual review of nutrition, v. 8, n. 1, p. 375399, 1988.

[8] DIFFEY, B. L. The consistency of studies of ultraviolet erythema in normal human skin. Physics in medicine and biology, v. 27, n. 5, p. 715, 1982.

[9] PARISI, Alfio V.; GREEN, Adele; KIMLIN, Michael G. Diffuse Solar UV Radiation and Implications for Preventing Human Eye Damage. Photochemistry and photobiology, v. 73, n. 2, p. 135-139, 2001.

[10] DE GRUIJL, Frank R. UV-induced Immunosuppression in the Balance. Photochemistry and photobiology, v. 84, n. 1, p. 2-9, 2008.

[11] SILVA, APR de et al. Estimativa 2012: Incidência de câncer no Brasil. Ministério da Saúde. Instituto Nacional do Câncer- INCA. Disponível em:< http:// www. inca. gov.br/estimativa/2012/index.asp, 2011.

[12] MCKENZIE, Richard L. et al. Ozone depletion and climate change: impacts on UV radiation. Photochemical \& Photobiological Sciences, v. 10, n. 2, p. 182-198, 2011. 
[13] WATANABE, S. et al. Anthropogenic changes in the surface all-sky UV-B radiation through 1850-2005 simulated by an Earth system model. Atmospheric Chemistry and Physics, v. 12, n. 11, p. 5249-5257, 2012.

[14] HERMAN, Jay R. Global increase in UV irradiance during the past 30 years (19792008) estimated from satellite data. Journal of Geophysical Research: Atmospheres (1984-2012), v. 115, n. D4, 2010.

[15] HERMAN, J. R. et al. Changes in cloud and aerosol cover (1980-2006) from reflectivity time series using SeaWiFS, N7-TOMS, EP-TOMS, SBUV-2, and OMI radiance data. Journal of Geophysical Research: Atmospheres (1984-2012), v. 114 , n. D1, 2009.

[16] SEINFELD, John H.; PANDIS, Spyros N. Atmospheric chemistry and physics: from air pollution to climate change. John Wiley \& Sons, 2012.

[17] DA SILVA, Abel Antônio. A espessura óptica de aerossóis na banda do UV-B. SILVA, v. 551, p. 17, 2001.

[18] FITZKA, M.; HADZIMUSTAFIC, J.; SIMIC, S. Total ozone and Umkehr observations at Hoher Sonnblick 1994-2011: Climatology and extreme events. Journal of Geophysical Research: Atmospheres, 2014.

[19] ANTÓN, M. et al. Extreme ultraviolet index due to broken clouds at a midlatitude site, Granada (southeastern Spain). Atmospheric Research, v. 118, p. 10-14, 2012.

[20] KATZ, Richard W.; BROWN, Barbara G. Extreme events in a changing climate: variability is more important than averages. Climatic change, v. 21, n. 3, p. 289-302, 1992.

[21] RAMOS, Andreas Malheiros; DOS SANTOS, Luiz André Rodriques. Normais climatológicas do Brasil 1961-1990: edição revista e ampliada. INMET, 2009.

[22] GES DISC-Data base of NASA-Goddard Earth Sciences Data and Information Services Center. Disponível em:< http://avdc.gsfc.nasa.gov/, 2013.

[23] LEPTOUKH, G. et al. NASA GES DISC on-line visualization and analysis system for gridded remote sensing data. In: 31st Int. Symp. Remote Sensing Environment, St. Petersburg, Russia. 2005.
[24] BRAMSTEDT, K. et al. Comparison of total ozone from the satellite instruments GOME and TOMS with measurements from the Dobson network 1996-2000. Atmospheric Chemistry and Physics, v. 3, n. 5, p. 1409-1419, 2003.

[25] JÉGOU, Fabrice et al. Validity of satellite measurements used for the monitoring of UV radiation risk on health. Atmospheric Chemistry and Physics Discussions, v. 11, n. 6, p. 17375-17421, 2011.

[27] KROTKOV, N. A. et al. OMI surface UV irradiance algorithm. Algorithm Theoretical Baseline Document: Clouds, Aerosols, and Surface UV Irradiance, v. 3, 2002.

[28] TORRES, Omar et al. Aerosols and surface UV products from Ozone Monitoring Instrument observations: An overview. Journal of Geophysical Research: Atmospheres (1984-2012), v. 112, n. D24, 2007.

[29] TANSKANEN, Aapo et al. Validation of daily erythemal doses from Ozone Monitoring Instrument with ground-based UV measurement data. Journal of Geophysical Research: Atmospheres (1984-2012), v. 112, n. D24, 2007.

[30] IALONGO, I.; CASALE, G. R.; SIANI, A. M. Comparison of total ozone and erythemal UV data from OMI with ground-based measurements at Rome station. Atmospheric Chemistry and Physics, v. 8, n. 12, p. 3283-3289, 2008.

[31] MCKINLAY, A. F.; DIFFEY, B. L. A reference action spectrum for ultraviolet induced erythema in human skin. CIE j, v. 6, n. 1, p. 17-22, 1987.

[31] LOPO, Alexandre Boleira et al. Ozone and Aerosol Influence on Ultraviolet Radiation on the East Coast of the Brazilian Northeast. Atmospheric and Climate Sciences, v. 4, p. 92, 2013.

[32] LOPO, Alexandre Boleira et al. Radiação ultravioleta, ozônio total e aerossóis na cidade de Natal-RN. HOLOS-ISSN 1807-1600, v. 6, p. 3-21, 2013. 